\title{
NMR study of gallosilicate natrolite
}

\author{
A.A.Sapiga, M.Olszewski*, M.Paczwa*, A.V.Sapiga, N.A.Sergeev" \\ Faculty of Physics, Taurida National V.Vernadsky University, \\ 295007 Simferopol, Ukraine \\ "Institute of Physics, University of Szczecin, \\ 15 Wielkopolska Str., 70-451 Szczecin, Poland
}

Received October 25, 2013

Solid-state ${ }^{29} \mathrm{Si},{ }^{27} \mathrm{Al}$ and ${ }^{71} \mathrm{Ga}$ NMR MAS spectroscopy was used to study the natural mineral - natrolite $\left(\mathrm{Na}_{16} \mathrm{Al}_{16} \mathrm{Si}_{24} \mathrm{O}_{80} \cdot 16 \mathrm{H}_{2} \mathrm{O}\right)$ and gallosilicate $\mathrm{Na}_{16} \mathrm{Ga}_{16} \mathrm{Si}_{24} \mathrm{O}_{80} \cdot 16 \mathrm{H}_{2} \mathrm{O}$ (Ga-natrolite). It has been shown that these natrolites form have sufficiently well-ordered structure also and contain $\mathrm{Si}\left(\mathrm{MO}_{4}\right)_{3}\left(\mathrm{SiO}_{4}\right)$ and $\mathrm{Si}\left(\mathrm{MO}_{4}\right)_{2}\left(\mathrm{SiO}_{4}\right)_{2}$ (where $\mathrm{M}=\mathrm{Al}$ or $\mathrm{Ga}$ ) structural units mainly. Our ${ }^{71} \mathrm{Ga}$ NMR MAS results indicate that in Ga-natrolite there are at least two different $\mathrm{Ga}$ cations with ratio $(10: 1)$.

Методами ЯMP MAS спектроскопии твердого тела ядер ${ }^{29} \mathrm{Si},{ }^{27} \mathrm{Al},{ }^{71} \mathrm{Ga}$ исследован минерал натролит $\left(\mathrm{Na}_{16} \mathrm{Al}_{16} \mathrm{Si}_{24} \mathrm{O}_{80} \cdot 16 \mathrm{H}_{2} \mathrm{O}\right)$ и галлосиликат $\mathrm{Na}_{16} \mathrm{Ga}_{16} \mathrm{Si}_{24} \mathrm{O}_{80} \cdot 16 \mathrm{H}_{2} \mathrm{O}(\mathrm{Ga}$ натролит). Показано, что эти формы натролита имеют хорошо упорядоченную структуру и содержат структурные единицы $\mathrm{Si}\left(\mathrm{MO}_{4}\right)_{3}(\mathrm{SiO} 4)$ и $\mathrm{Si}\left(\mathrm{MO}_{4}\right)_{2}\left(\mathrm{SiO}_{4}\right)_{2}$ (где $\mathrm{M}=\mathrm{Al}$ или $\left.\mathrm{Ga}\right)$. Результаты ЯMP MAS ${ }^{71} \mathrm{Ga}$ показали, что в Ga-натролите имеется, по крайней мере, два разных $\mathrm{Ga}$ катиона с отношением (10:1).

Дослідження галосилікату типу натроліту методом ЯМР. O.O.Caniza, М.Ольшевський, М.Пачва, О.В.Сапіга, М.О.Сергєєв.

Методами ЯMP MAS спектроскопії твердого тіла на ядрах ${ }^{29} \mathrm{Si},{ }^{27} \mathrm{Al},{ }^{71} \mathrm{Ga}$ досліджено мінерал натроліт $\left(\mathrm{Na}_{16} \mathrm{Al}_{16} \mathrm{Si}_{24} \mathrm{O}_{80} \cdot 16 \mathrm{H}_{2} \mathrm{O}\right)$ та галлосилікат $\mathrm{Na}_{16} \mathrm{Ga}_{16} \mathrm{Si}_{24} \mathrm{O}_{80} \cdot 16 \mathrm{H}_{2} \mathrm{O}(\mathrm{Ga}$ натроліт). Показано, що ці форми натроліту мають добре впорядковану структуру $\mathrm{i}$ містять структурні одиниці $\mathrm{Si}\left(\mathrm{MO}_{4}\right)_{3}\left(\mathrm{SiO}_{4}\right)$ i $\mathrm{Si}\left(\mathrm{MO}_{4}\right)_{2}(\mathrm{SiO} 4) 2$ (де $\mathrm{M}=\mathrm{Al}$ або $\left.\mathrm{Ga}\right)$. За результатами ЯMP MAS ${ }^{71} \mathrm{Ga}$ показано, що Gа-натроліт має, принаймні, два різних катіона галію з співвідношенням (10:1).

\section{Introduction}

Zeolites are crystalline, microporous solids that, as functional materials, have found a broad spectrum applications as catalysis and separation media in the different ranges of commercial application and petrochemical industry [1-4]. Zeolites are three-dimensional, crystalline networks of tetrahedra $\mathrm{AlO}_{4}$, and $\mathrm{SiO}_{4}$ [1]. Tetrahedra are corner connected through a flexible oxygen bridge to give an extended structure of $\mathrm{Al}$ and Si tetrahedra. The tetrahedral $\mathrm{AlO}_{4}$, and $\mathrm{SiO}_{4}$ can combine in a number of different ways to give huge structural variety in the zeolite family. Arrangement of $\mathrm{TO}_{4}(\mathrm{~T}=$ Al or Si) tetrahedral can be described in terms of primary and secondary building units [1].

At present there has been considerable interest in the isomorphous replacement of Al atoms by other trivalent cations because these replaced zeolites possess different physical and chemical properties from their aluminum analogues and offer the possibilities of new applications of these molecular sieves. Since gallium is directly below aluminium in the periodic table, they form chemically similar $\mathrm{GaO}_{4}$ and $\mathrm{AlO}_{4}$ tetrahedra. Isomorphous substitution of $\mathrm{Ga}$ for $\mathrm{Al}$ in alu- 


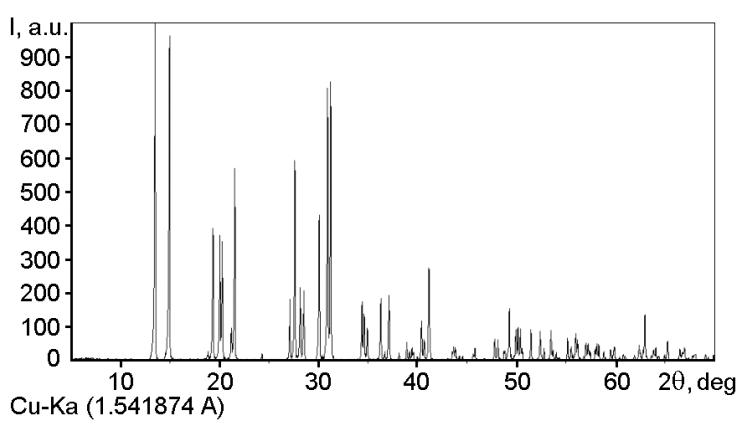

Fig. 1. Powder X-ray diffraction pattern of gallium natrolite prepared in this study.

mosilicate natrolite $\left(\mathrm{Na}_{16} \mathrm{Al}_{16} \mathrm{Si}_{24} \mathrm{O}_{80} \cdot 16 \mathrm{H}_{2} \mathrm{O}\right)$ gives gallosilicate natrolite (Ga-natrolite) [1]. There are two synthetic forms of gallosilicate natrolite, orthorhombic $\left(\mathrm{Na}_{16} \mathrm{Ga}_{16} \mathrm{Si}_{24} \mathrm{O}_{80} \cdot 16 \mathrm{H}_{2} \mathrm{O}\right)$ and tetragonal $\left(\mathrm{Na}_{8} \mathrm{Ga}_{8} \mathrm{Si}_{12} \mathrm{O}_{40} \cdot 8 \mathrm{H}_{2} \mathrm{O}\right)$ [5,6]. These forms differ in the ordering of $\mathrm{Si}$ or $\mathrm{Ga}$ atoms.

The NMR MAS spectroscopy is the one of the main methods for studying the microstructure of materials, including zeolites [7]. In present paper the results of study of orthorhombic natural Al-natrolite $\left(\mathrm{Na}_{16} \mathrm{Al}_{16} \mathrm{Si}_{24} \mathrm{O}_{80} \cdot 16 \mathrm{H}_{2} \mathrm{O}\right)$ and gallosilicate natrolite $\left(\mathrm{Na}_{16} \mathrm{Ga}_{16} \mathrm{Si}_{24} \mathrm{O}_{80} \cdot 16 \mathrm{H}_{2} \mathrm{O}\right)$ by means of NMR MAS of ${ }^{29} \mathrm{Si},{ }^{27} \mathrm{Al}$ and ${ }^{71} \mathrm{Ga}$ nuclei have been presented. The obtained results for two Al- and Ga-natrolites have been compared with published results [8-10].

\section{Experimental}

The polycrystalline samples of natural Alnatrolite from Khibiny deposit (Kola Peninsula, Russia) were used in this study. The gallium form of natrolite was hydrothermally synthesized as described in [10]. Water solution of gallium oxide $\left(\mathrm{Ga}_{2} \mathrm{O}_{3}\right.$, 99.99\%, Aldrich) and sodium hydroxide (50\% aqueous solution, Aldrich) were heated up to $100^{\circ} \mathrm{C}$ and stirred over night. After cooling to room temperature the colloidal silica (Ludox AS-40) were slowly added, with stirring. The result mixture with oxide composition $6.0 \mathrm{Na}_{2} \mathrm{O} \cdot 1.0 \mathrm{Ga}_{2} \mathrm{O}_{3}$. $10.0 \mathrm{SiO}_{2} \cdot 150 \mathrm{H}_{2} \mathrm{O}$ was charged into Teflonlined $100 \mathrm{~mL}$ autoclave and heated up to $170^{\circ} \mathrm{C}$. After 12 days the autoclave was cooled down, the products were washed for three times with water and dried over night in the oven.

Powder X-ray data (XRD) were collected on PANalytical XPERT-PRO diffractometer with $\mathrm{CuK}_{\alpha}$ radiation of wavelength $1.541874 \AA$. The samples were analyzed in

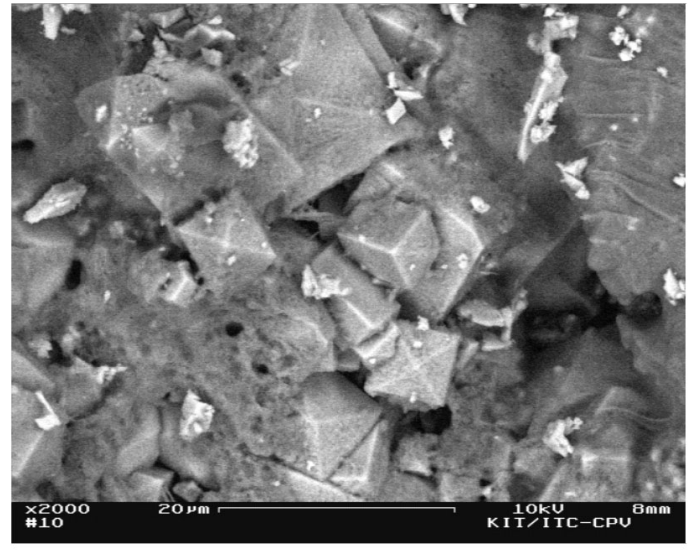

Fig. 2. Scanning electron micrographs of the gallium natrolite.

Table. Data of chemical analyses of gallium and natural natrolites. $M$ is $\mathrm{Ga}$ for gallium natrolite and Al for natural natrolite

\begin{tabular}{||c|c|c|c|c|c||}
\hline Sample & $\mathrm{Si}$ & $\mathrm{M}(\mathrm{Ga})$ & $\mathrm{Na}$ & $\mathrm{O}$ & $\mathrm{Si} / \mathrm{M}$ \\
\hline Ga natrolite & 15.41 & 9.85 & 8.73 & 66.02 & 1.565 \\
$\begin{array}{c}\text { Natural } \\
\text { Al-natrolite }\end{array}$ & 14.77 & $\begin{array}{c}8.92 \\
\mathrm{(Al})\end{array}$ & 9.05 & 67.27 & 1.656 \\
\hline
\end{tabular}

the $2 \theta$ range $5-70^{\circ}$ in steps of $0.017^{\circ}$ (Fig. 1). The phases were identified by comparing the diffraction peaks with the data reported in ICSD (Inorganic Crystal Structure Database) using X'Pert HighScore program. According to ICSD the result XRD pattern match NAT topology and it is in a good agreement with material TNU-4 in [10]. This shows that we have a deal with gallium form of natrolite.

Chemical analyses of synthesized gallium natrolite and natural natrolite were performed with a DSM 982 Gemini FESEM scanning electron microscope (SEM) ZEISS. The detector had a inlens and lateral electron (SE) detector and a backscatter electron (BSE) detector. For the individual SEM images were most often used BSEDetektor. The respective excitation voltage was $0.265 \mathrm{keV}$. Chemical analyses are summarized in Table, where $M$ is $\mathrm{Ga}$ for gallium natrolite and $\mathrm{Al}$ for natural natrolite. In sample of natural natrolite there are small contents $(\cong 0.02 \%)$ of $\mathrm{CaO}, \mathrm{K}_{2} \mathrm{O}, \mathrm{SrO}$ and $\mathrm{Fe}_{2} \mathrm{O}_{3}$. In Fig. 2 it could be found SEM picture of small crystals produced by hydrothermal synthesis.

All NMR MAS spectra were obtained on polycrystalline sample of Al- and Ga-natrolite on a Bruker Avance-400 NMR spectrometer. The ${ }^{29} \mathrm{Si}$ MAS NMR spectra were 
measured at a spinning rate of $10 \mathrm{kHz}$ using $4 \mathrm{~mm}$ rotors at a ${ }^{29} \mathrm{Si}$ frequency of $79.490 \mathrm{MHz}$ with $\pi / 2$ pulse length of $3 \mu \mathrm{s}$. Typically 10000 scans were accumulated and the ${ }^{29} \mathrm{Si}$ chemical shifts are referenced to TMS. The ${ }^{71} \mathrm{Ga}$ MAS NMR spectra were obtained at a ${ }^{71} \mathrm{Ga}$ frequency of $122.0564 \mathrm{MHz}$ in $4 \mathrm{~mm}$ rotors at a spinning rate of $14.0 \mathrm{kHz}$. The spectra were obtained with an acquisition of 1000 pulse transients, which was repeated with $R F$ pulse length of $2.4 \mu \mathrm{s}$. The ${ }^{27} \mathrm{Al}$ MAS NMR spectra were measured at a spinning rate of $10 \mathrm{kHz}$ at a ${ }^{27} \mathrm{Al}$ frequency of 104.2665 $\mathrm{MHz}$ with $\pi / 2$ pulse length of $1.7 \mu \mathrm{s}$. Simulation of ${ }^{27} \mathrm{Al}$ and ${ }^{71} \mathrm{Ga}$ MAS NMR spectra obtained were carried out using the formulas represented in [11].

\section{Results and discussion}

Fig. 3 show the ${ }^{29}$ Si MAS NMR spectra of Al- and Ga-natrolites. From these figures it follows that the ${ }^{29} \mathrm{Si}$ MAS NMR spectra of Al- and Ga-natrolite are similar and contain two resonant lines. In natural Al-natrolite the two resonance lines of ${ }^{29} \mathrm{Si} \mathrm{MAS}$ NMR spectrum at $-84.9 \mathrm{ppm}$ and $-92.7 \mathrm{ppm}$ with an intensity ratio of $\approx 2: 1$, observed in our investigations (Fig. 3). The different of the chemical shifts of two resonance lines of ${ }^{29} \mathrm{Si}$ atoms is $7.8 \mathrm{ppm}$.

It has been demonstrated at first by Lipmaa et al. [12] that the chemical shifts of ${ }^{29} \mathrm{Si}$ MAS NMR spectra of zeolite and other aluminoosilicates are sensitive to the number of $\mathrm{AlO}_{4}$ tetrahedra linked to the $\mathrm{SiO}_{4}$ tetrahedron, also described as the second coordination sphere of silicon. The number of aluminium tetrahedra sharing oxygens with the $\mathrm{SiO}_{4}$ tetrahedron under consideration and define five different structural units in the alumosilicate framework, namely, $\mathrm{Si}(n \mathrm{Al})$, where index $n=0,1,2,3,4$ defines the number of aluminium tetrahedra connected with $\mathrm{SiO}_{4}$ tetrahedron. ${ }^{29} \mathrm{Si}$ chemical shift ranges with about 5 ppm low-field shifts for each additional substituent have been connected [12]. This allows to establish the structures of various zeolites and to get information about Si/Al ordering.

The orthorhombic Al-natrolite (space group $F d d 2$ ) has three different central sites ( $T$-sites) in tetrahedra $\mathrm{TO}_{4}$ with multiplicities 8:16:16. According to the X-ray and NMR structure determination study of natural natrolite $[12,13]$, the natural Al-natrolite has a well-ordered structure with $\mathrm{Si} / \mathrm{Al}$ ratio $(3: 2)[7,12]$. To achieve a Si/Al

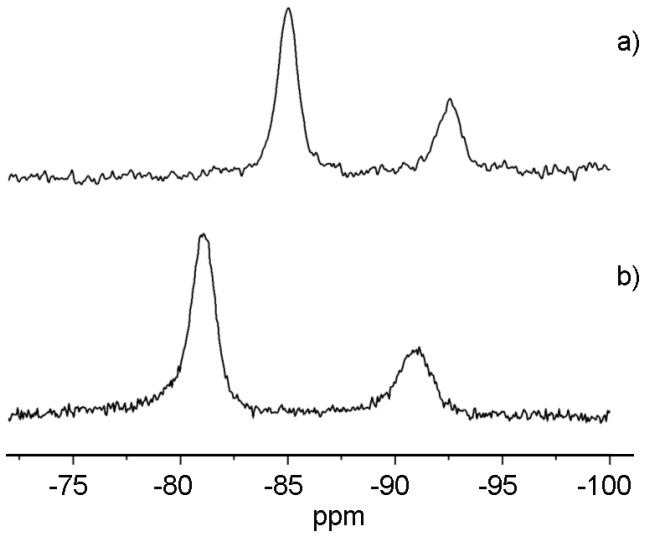

Fig. 3. ${ }^{29} \mathrm{Si}$ MAS NMR spectra of Al-natrolite (a) and Ga-natrolite (b).

ratio equals 1.5 to give only two type of silicon atoms - those connected to three $\mathrm{AlO}_{4}$ tetrahedra and one $\mathrm{SiO}_{4}$ tetrahedron $\left(\mathrm{Si}\left(\mathrm{AlO}_{4}\right)_{3}\left(\mathrm{SiO}_{4}\right)\right)$ and those connected to two $\mathrm{AlO}_{4}$ tetrahedra and two $\mathrm{SiO}_{4}$ tetrahedra $\left(\mathrm{Si}\left(\mathrm{AlO}_{4}\right)_{2}\left(\mathrm{SiO}_{4}\right)_{2}\right)$ in $2: 1$ ratio, in accordance with its $\mathrm{Si} / \mathrm{Al}$ ratio $(3: 2)[7,12]$.

The two resonance lines at $-81.1 \mathrm{ppm}$ and -91.1 ppm observed in NMR MAS ${ }^{29} \mathrm{Si}$ spectrum (Fig. 3) of gallosilicate natrolite to point out that this natrolite has sufficiently well-ordered structure also and contains $\mathrm{Si}\left(\mathrm{GaO}_{4}\right)_{3}\left(\mathrm{SiO}_{4}\right)$ and $\left.\mathrm{Si}\left(\mathrm{GaO}_{4}\right)_{2}\left(\mathrm{SiO}_{4}\right)_{2}\right)$ structural units mainly. However, the intensity ratio of these two lines $(\approx 1.7)$ is somewhat unusual and gives a Si/Ga ratio not equal 1.5. It is possible from this result it follows that in the structure of gallosilicate natrolite there are other $\mathrm{Si}\left(\mathrm{GaO}_{4}\right)_{n}\left(\mathrm{SiO}_{4}\right)_{4-n}$ with $n=0,1,4$ structural units [9]. The intensities of NMR MAS ${ }^{29} \mathrm{Si}$ lines of these units may be so weak, that they are not observed experimentally. Further work is in progress to find the origin of the apparently anomalous $\mathrm{Si} / \mathrm{Ga}$ ratio in the gallosilicate natrolite. The different of the chemical shifts of two resonance lines of ${ }^{29} \mathrm{Si}$ atoms in Ga-natrolite is $10,0 \mathrm{ppm}$. It should be note that in the case of Al-natrolite it was assumed that there are order and disorder "domains" in the crystalline structure $[5,12]$. From our experimental results it follows that the same substructures there are in Ga-natrolite.

The aluminium atoms have four nearestneighbor oxygen atoms in tetrahedral coordination in Al-natrolite. The nucleus of aluminium atom has spin $I=5 / 2$ and it is quadrupolar nucleus. The quadrupole moment of the nucleus is a sensitive probe of the existence of a nonuniform electric field 


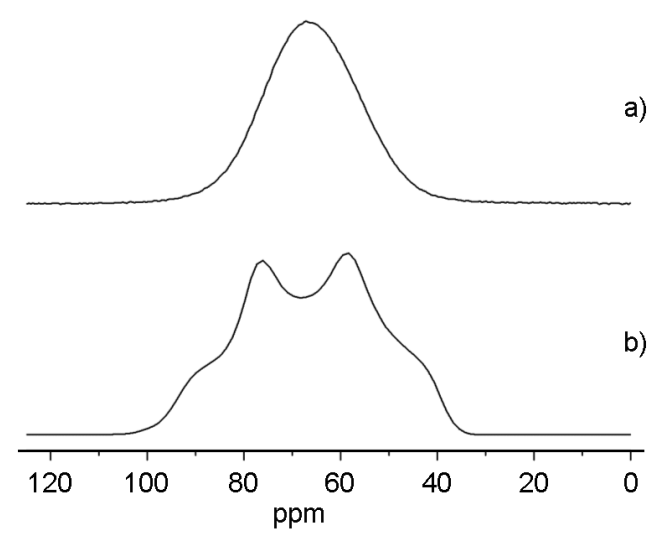

Fig. 4. Experimental (a) and theoretical (b) ${ }^{27} \mathrm{Al}$ MAS NMR spectra of Al-natrolite. A quadrupole coupling constant $\left(C_{Q}=e^{2} q Q / h\right)$ for ${ }^{27} \mathrm{Al}$ was equalled $1.663 \mathrm{MHz}$ with the asymmetry parameter $\eta=0.5[14]$.

(GEF) at the location of the nucleus. In ideal, nondistorted tetrahedron the GEF must be absented. But according to NMR data the GEF in Al-natrolite is not zero and quadrupole coupling constant $\left(C_{Q}=e^{2} q Q / h\right)$ for ${ }^{27} \mathrm{Al}$ is equalled $1.663 \mathrm{MHz}$ with the asymmetry parameter $\eta=0.5[11,14]$ From this result it follows that tetrahedron $\mathrm{AlO}_{4}$ in Al-natrolite is distorted. ${ }^{27} \mathrm{Al}$ NMR MAS spectrum of Al-natrolite is shown at Fig. 4. For quadrupole nuclei the shape of NMR MAS spectra is dominated by second-order quadrupolar interaction [11]. Figure 4 shows also a simulation of the ${ }^{27} \mathrm{Al}$ MAS NMR spectrum of Al-natrolite with quadrupolar parameters obtained in [14]. The theoretical spectrum shown at Fig. 4 is in good agreement with the experimental spectrum shown at this figure.

The experimental and simulated ${ }^{71} \mathrm{Ga}$ MAS NMR spectrum of Ga-natrolite are shown at Fig. 5. This figure clearly shows a line shape which is determined by secondorder quadrupolar interaction [11]. From Fig. 5 it follows that in Ga-natrolite there are at least two different $\mathrm{Ga}$ cations - $\mathrm{Ga}(\mathrm{I})$ and $\mathrm{Ga}(\mathrm{II})$ with $\mathrm{Ga}(\mathrm{I}) / \mathrm{Ga}(\mathrm{II})$ ratio (10:1). Fig. 5b shows a simulation of ${ }^{71} \mathrm{Ga}$ MAS NMR spectrum of Ga-natrolite. The ${ }^{71} \mathrm{Ga}$ MAS NMR spectrum of $\mathrm{Ga}(\mathrm{II})$ nuclei contains one Gaussian component with small parameters of GEF and spectrum $\mathrm{Ga}(\mathrm{I})$ has a quadrupolar structure with quadrupolar parameters $C_{Q}=4.0 \mathrm{MHz}$ and the asymmetry parameter $\eta=0.1$.

As already suggested above, it is also possible that there are crystalline domains in Ga-natrolite with different degrees of Si, Ga ordering, which would explained not

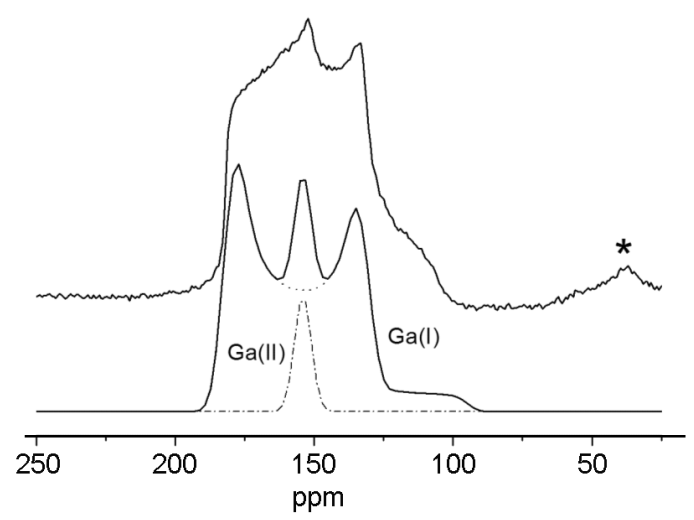

Fig. 5. Experimental (a) and theoretical (b) ${ }^{71} \mathrm{Ga}$ MAS NMR spectra of Ga-natrolite. Spinning sideband is marked by asterisk.

only the presence of at least two types of Ga cations in ${ }^{71} \mathrm{Ga}$ MAS NMR spectrum but also the unusual Si/Ga ratio for Ga-natrolite. Further work is in progress to find the origin of at least two different environments for $\mathrm{Ga}$ in Ga-natrolite.

If we assume that the two isostructural Al- and Ga-natrolites have identical electric field gradients (eq) than the ratio of quadrupolar coupling constants $\left(C_{Q}=e^{2} q Q / h\right)$ of $\mathrm{Al}$ and $\mathrm{Ga}$ nuclei must be equal to ratio of there quadrupolar moments $(Q)$. However the ratios $Q\left({ }^{27} \mathrm{Al}\right) / Q\left({ }^{71} \mathrm{Ga}\right)=1.32$ and $C_{Q}\left({ }^{27} \mathrm{Al}\right) / C_{Q}\left({ }^{71} \mathrm{Ga}\right)=0.33$ is not coincided with this assumption. The larger quadrupolar coupling constant $C_{Q}\left({ }^{71} \mathrm{Ga}\right)=4 \mathrm{MHz}$ than predicted from the ration of quadrupolar moments $Q\left({ }^{27} \mathrm{Al}\right) / Q\left({ }^{71} \mathrm{Ga}\right)$ may not originate from the increased ionic radius of $\mathrm{Ga}^{3+}$ $(0.62 \AA)$ over $\mathrm{Al}^{3+}(0.5 \AA)$. The larger ionic radius of $\mathrm{Ga}$ cation induces structural changes of $\mathrm{GaO}_{4}$ tetrahedron and results in more distortion around gallium in Ga-natrolite. So as gradient of electric field $q \sim 1 / r^{3}$ (where $r$ is the distance between $\mathrm{Ga}$ position and charge of surrounding his ion) this deformation of $\mathrm{GaO}_{4}$ tetrahedron does not probably induces to larger quadrupolar coupling constant. Moreover, the greater electronegativity of $\mathrm{Ga}$ compared to Al will lead to increased $p$-orbitals contributions to the quadrupolar coupling constant, resulting in larger $C\left({ }^{71} \mathrm{Ga}\right)$ value than predicted from the ratio of the quadrupolar moments $Q\left({ }^{27} \mathrm{Al}\right) / Q\left({ }^{71} \mathrm{Ga}\right)$. At last the contribution of the inner closed-shell electrons to the electric field gradient at the site of nucleus (so-called Sternheimer shielding parameter) is larger for $\mathrm{Ga}^{3+}$ than for $\mathrm{Al}^{3+}$ which will 
lead to $C\left({ }^{71} \mathrm{Ga}\right)$ value that is larger than may be assume.

\section{Conclusions}

From the comparative analysis of the obtained NMR MAS spectra of ${ }^{29} \mathrm{Si},{ }^{25} \mathrm{Al}$ and ${ }^{71} \mathrm{Ga}$ nuclei in Al- and Ga-natrolites we may conclude that the natural Al- and synthetic gallosilicate natrolite have a well-ordered structure with Si/Al ratio $(3: 2)$ which contain tetrahedra $\left(\mathrm{Si}\left(\mathrm{Al}, \mathrm{GaO}_{4}\right)_{3}\left(\mathrm{SiO}_{4}\right)\right)$ and $\left(\mathrm{Si}\left(\mathrm{Al}, \mathrm{GaO}_{4}\right)_{2}\left(\mathrm{SiO}_{4}\right)_{2}\right)$ in 2:1 ratio. From the experimental and simulated ${ }^{71} \mathrm{Ga}$ MAS NMR spectrum of Ga-natrolite it follows that NMR line shape is determined by secondorder quadrupolar interaction and in Ga-natrolite there are at least two different $\mathrm{Ga}$ cations - $\mathrm{Ga}(\mathrm{I})$ and $\mathrm{Ga}(\mathrm{II})$ with $\mathrm{Ga}(\mathrm{I}) / \mathrm{Ga}$ (II) ratio (10:1).

Acknowledgments. We thank Olaf Walter for XRD pattern studies, Philipp Becker for participation in hydrothermal synthesis, Wilhelm Habicht for scanning electron/scanning probe microscopy, from Institute of Technical Chemistry Division of Chemical-Physical Processing (ITC/CPV), Karlsruhe Institute of Technology (KIT).

\section{References}

1. D.W.Breck, Zeolite Molecular Sieves, Wiley, New York (1974).
2. J.Weitkamp, in: Catalysis and Absorption by Zeolites, ed. by G.Olhmann, J.C.Vedrine and P.A.Jacobs, Elsevier, Amsterdam (1991).

3. J.M.Newsam, Zeolites, in: Solid State Chemistry: Compound, ed. by A.K.Cheetham and P.Day, Oxford University Press, Oxford (1992).

4. S.M.Auerbach, H.I.Metiu, J.Chem.Phys., 106, 2893 (1997).

5. S.B.Hong, S.H.Kim, Y.G.Kim et al., J.Mater. Chem., 9, 2287 (1999).

6. S.B.Hong, S.H.Lee, C.-H.Shin et al., J.Am. Chem.Soc., 126, 13742 (2004).

7. G.Engelhardt, D.Michel, High-Resolution Solid-State NMR of Silicates and Zeolites, Wiley, New York (1987).

8. A.V.Sapiga, Thesis, V.Vernadsky Tavrida National University, Simferopol, Ukraine, 2003.

9. H.K.C.Timken, E.Oldfield, J.Amer.Chem. Soc., 109, 7669 (1987).

10. H.H.Cho, S.H.Kim, Y.G.Kim et al., Chem. Mater., 12, 2292 (2000).

11. D.Freude, in: Encyclopedia of Analytical Chemistry, ed. by R.A.Meyers, John Wiley\&Sons Ltd, Chichester (2000).

12. E.Lippmaa, M.Magi, A.Samoson et al., J.Am. Chem.Soc., 103, 4992 (1981)

13. W.M.Meier, Z. Kristallogr., 113, 430 (1960)

14. H.E.Petch, K.S.Pennington, J.Chem.Phys., 36, 1216 (1967). 